\title{
Development of New Strategy for Non-Antibiotic Therapy: Dromedary Camel Lactoferrin Has a Potent Antimicrobial and Immunomodulator Effects*
}

\author{
Alaa B. Ismael ${ }^{1,2 \#}$, Salama M. Abd El Hafez ${ }^{3,4}$, Manal B. Mahmoud ${ }^{4}$, Abdel-Kader A. Elaraby, \\ Hany M. Hassan ${ }^{4}$ \\ ${ }^{1}$ Department of Medical Biotechnology, Faculty of Applied Medical Sciences, Taif University, Turaba, KSA; ${ }^{2}$ Department of Animal \\ Medicine, Faculty of Veterinary Medicine, Zagazig University, Zagazig, Egypt; ${ }^{3}$ Department of Medical Microbiology, Faculty of \\ Applied Medical Sciences, Taif University, Turaba, KSA; ${ }^{4}$ Immunobiology and Immunopharmacology Unit, Animal Reproduction \\ Research Institute (ARRI), Giza, Egypt; ${ }^{5}$ Holding Company for Biological Products \& Vaccines VACSERA, Giza, Egypt. \\ Email: \#alismae17@gmail.com
}

Received August $27^{\text {th }}, 2013$; revised September $26^{\text {th }}, 2013$; accepted October $3^{\text {rd }}, 2013$

Copyright (C) 2013 Alaa B. Ismael et al. This is an open access article distributed under the Creative Commons Attribution License, which permits unrestricted use, distribution, and reproduction in any medium, provided the original work is properly cited.

\begin{abstract}
The human and bovine lactoferrin have been studied extensively, but very few reports have been published concerning camel lactoferrin (cLf). The present study aimed to isolate $\mathrm{cLf}$ and evaluate its efficiency including antimicrobial activity and immunomodulator effects. cLf isolation was attempted from camel milk whey using a cation exchange chromatography by SP-Sepharose. The antimicrobial activity of the isolated cLf was investigated against Staphylococcus aureus (S. aureus), Streptococcus agalactiae (S. agalactiae), Escherichia coli (E. coli) and Pseudomonas aeruginosa (P. aerogenosa) strains. The immune effect of $\mathrm{cLf}$ was studied by lymphocyte transformation test. It was found that cLf was separated around molecular weight of $80 \mathrm{kDa}$ and showed significant inhibitory effect against $E$. coli followed by $P$. aeruginosa, S. agalactiae and S. aureus. cLf increased lymphocyte transformations mean values in a dose dependant manner. The highest transformations mean value was determined at $50 \mu \mathrm{g} / \mathrm{mL}$. In conclusion, these results suggest that cLf is a potent natural antimicrobial and novel immunomodulator agent.
\end{abstract}

Keywords: Dromedary Camel Lactoferrin; Isolation; Antimicrobial and Immunomodulator Effects

\section{Introduction}

Few studies have been reported on camels and camel milk [1]. Dromedary camel milk and their products are a good nutritional source for the people living in the arid and urban areas. In addition, fresh and fermented camel milk were reported to provide particular health benefits to the consumer depending on the bioactive substances in milk [2]. Antibiotics are commonly used for both prophylaxis and treatment of various bacterial infections in human and farm animals. In recent years, antibiotics resistance in bacteria of animal origin and its impact on human health have drawn much attention worldwide [3]. Bovine mastitis is the most common cause for the use of antibiotics agents in lactating dairy cattle [4] and the detection of antibiotics residues in milk poses health haz-

\footnotetext{
*No conflict of interest to declare.
}

${ }^{\#}$ Corresponding author. ards to consumers, and the cause of high economic importance because such milk is unfit for processing and subsequent consumption [5]. Moreover, the antibiotic therapy has many complications as hypersensitivity, direct toxicity, antibiotic-induced immunosuppresion and super-infections. This is highlighting the need for a new strategy for non-antibiotic therapy using novel immunomodulators as naturally released immunomodulators (Lactoferrin (Lf), cathelicidins and defenses) or bacterial products (Periplasmic proteins and lipopolysaccharides).

Lactoferrin (Lf), is an iron-binding glycoprotein found in a variety of body secretions including tears, bronchial mucus, and saliva and it is found in high concentrations in the mammary secretions of nonlactating dairy animals. It is important in regulation of iron metabolism [6]. This natural antimicrobial agent is a multifunctional bioactive molecule with a critical role in many important physio- 
logical pathways. Lf could elicit a variety of inhibitory effects against microorganisms, comprising stasis, cidal, adhesion-blockade, cationic, synergistic, and opsonic mechanisms. Broad-spectrum activities against different bacteria, viruses, fungi, and parasites, in combination with anti-inflammatory and immunomodulatory properties, make Lf a potent innate host defense mechanism [7]. The large potential applications of $\mathrm{Lf}$ have led scientists to develop this nutraceutical protein for use in feed, food and pharmaceutical applications.

Camel lactoferrin (cLf) purification, biochemical, and immunological characterization have shown its similarity to human and bovine Lf, as well as the cross-react with the anti-human Lf antibodies [8-10]. The amounts of lactoferrin and immunoglobulins were found to be greater in dromedary camel milk than bovine or buffalo milk $[8,10,11]$. Incubation of human leukocytes with cLf leads to a complete virus entry inhibition after seven days' incubation. Thus, cLf markedly inhibits hepatitis $\mathrm{C}$ virus genotype 4 infection of human peripheral blood leukocytes [12]. The miR-214 is directly involved in Lf expression and Lf mediated cancer susceptibility (proapoptotic activities) in mammary epithelial cells [13].

Many processing technologies have been developed to isolate the high purity fraction of Lf. And most of the technologies use a cation exchange chromatography on SP-Sepha-rose $[14,15]$.

The aim of this investigation was mainly to isolate cLf from camel milk whey and evaluate its efficacy in vitro including antimicrobial and immunomodulator effects. We use cLf but not bovine Lf because cLf is more bioactive [16].

\section{Materials and Methods}

\subsection{Isolation of Lactoferrin from Camel Milk Whey}

Lactoferrin (Lf) isolation was attempted from camel milk whey. It was purified using a cation exchange chromatography on SP-Sepharose following the procedure that previously described [14]. Briefly, milk whey was obtained from camel milk using ultra speed centrifuge, $15000 \times \mathrm{g}$ at $4^{\circ} \mathrm{C}$ for $30 \mathrm{~min}$. Skimmed milk was then diluted 1:1 with the dilution buffer $\left(0.04 \mathrm{M} \mathrm{NaH}_{2} \mathrm{PO}_{4}, 0.8\right.$ $\mathrm{M} \mathrm{NaCl}, 0.04 \%$ (v/v) Tween 20, $\mathrm{pH} 7.4$ ) and it was incubated with SP-Sepharose at $4^{\circ} \mathrm{C}$ overnight. Afterwards, the SP-Sepharose was washed with the washing buffer (0.02 $\mathrm{M} \mathrm{NaH}_{2} \mathrm{PO}_{4}, 0.4 \mathrm{M} \mathrm{NaCl}, 0.02 \%$ (v/v) Tween 20, $\mathrm{pH}$ 7.4) to elude the unbound proteins. The gel then packed into a column $(5 \times 30 \mathrm{~cm}$ or $3 \times 30 \mathrm{~cm}$, depending on the milk volume) and lactoferrin was eluted with the elution buffer $\left(0.02 \mathrm{M} \mathrm{NaH}_{2} \mathrm{PO}_{4}, 1 \mathrm{M} \mathrm{NaCl}, \mathrm{pH} 7.4\right)$. The column was run at a flow rate of $3 \mathrm{~mL} / \mathrm{min}$.

\subsection{Electrophoresis of Milk and Fractions Containing Lactoferrin}

Purity control and characterization of camel Lf (cLf) was done using sodium dodecyl sulfate-polyacrylamide gel electrophoresis (SDS-PAGE). Collected fractions of camel milk whey and broad range protein ladder (Fermentra SM1841) were resolved in $12 \%$ polyacrylamide minigel-protein II electrophoresis cell (Bio-Rad). Samples were diluted in sample buffer 2-mercaptoethanol (Sigma Chemical Co.), boiled for 5 minutes before being loaded in the gels and run at 70 volts for 3 hours. Gels were stained with 1\% Coomassie blue R-250 (Sigma Chemical Co.), then distained at room temperature in 5\% methanol and $7.5 \%$ acetic acid with shaking for 30 minutes. The different fractions were quantified using Bio-Rad GS 700 imaging densitometer molecular analysis software against broad range marker [17].

\subsection{Antimicrobial Activity Assays}

Escherichia coli (E. coli), Pseudomonas aeruginosa ( $P$. aerogenosa), Staphylococcus aureus (S. aureus) and Streptococcus agalactiae (S. agalactiae) isolates were used to study the antimicrobial activity of cLf. The tested microorganisms were kept in their specific soft agar. Working cultures were obtained by growing the tested isolates on their specific media. After an overnight incubation, an isolated colony was transferred to $10 \mathrm{~mL}$ of Mueller-Hinton broth (MHB, Difco Laboratories, Detroit, MI) and incubated at $37^{\circ} \mathrm{C}$ for $16-20 \mathrm{~h}$. Final concentration of $1 \times 10^{6} \mathrm{CFU} / \mathrm{mL}$ was used. A volume of $1 \mathrm{~mL}$ of cLf solution in different concentrations ( 1 and $3 \mathrm{mg} / \mathrm{mL}$ ) was added to 4 wells of tissue culture plates (NUNC. A/S, Roskilde, Denmark) for each of tested microorganisms as previously described [18]. The tested microorganisms in phosphate buffer saline (PBS, $10 \mathrm{mM}, \mathrm{pH}$ 7.4) was used a control. Plates were incubated at $37^{\circ} \mathrm{C}$. Aliquots were removed after 1, 3, 6, 12, 24 hours and ten serially diluted, then plated at $37^{\circ} \mathrm{C}$ on Mueller Hinton agar (MHA, Difco Laboratories, Detroit, MI) to be counted after $48 \mathrm{~h}$ incubation. Total aerobic bacterial count (TBC) of tested microorganisms was done in which viable aerobic mesophlic bacteria were determined as previously described [19]. All equipments used were either sterile new glass or plastic to avoid iron contamination. All experiments were repeated at least two times.

\subsection{In Vitro Lymphocyte Proliferation Studies}

Lymphocyte proliferation test using MTT (3-(4, 5-dimethyl thiazol-2-yl) 2, 5-diphenyl tetrazolium bromide) was performed [20] with modification. Briefly, heaprinized calf blood samples were aseptically collected 
in sterile tubes. The separation of lymphocytes was done by layering of blood in Ficol (2:1) and centrifuged at 400 $\times \mathrm{g}$ at $4^{\circ} \mathrm{C}$ for 30 minutes to give packed blood cells with granulocyte, interface layer (which contain lymphocytes) and upper plasma layer. The interface layer was carefully aspirated using sterile glass Pasteur pipette, then placed in sterile tubes containing $2 \mathrm{~mL}$ RPMI 1640 medium. Cells were washed 3 times with RPMI 1640 medium by centrifugation at $400 \times \mathrm{g}$ for $10 \mathrm{~min}$ at $4^{\circ} \mathrm{C}$. After the last wash, the sediment lymphocytes were resuspended in 1 $\mathrm{mL}$ of RPMI 1640 medium containing 10\% fetal calf serum (FCS). RBCs contamination, if any, was removed by the distilled water lysis method. Lymphocytes were seeded in triplicate in flat-bottom 96-well micro titer plates (Costar) at $1 \times 10^{6}$ cells per well in $150 \mu \mathrm{L}$ of culture medium either alone or with various concentrations of $\operatorname{cLf}(10 \mu \mathrm{g} / \mathrm{mL}, 20 \mu \mathrm{g} / \mathrm{mL}$ and $50 \mu \mathrm{g} / \mathrm{mL})$ or $15 \mu \mathrm{g}$ of Phytohemagglutinin (PHA) control per mL. Another 100 $\mu \mathrm{L}$ of cell suspension was added to three sets of triplicate wells of a RPMI-1640 containing different concentration of cLf $(10 \mu \mathrm{g} / \mathrm{mL}, 20 \mu \mathrm{g} / \mathrm{mL}$ and $50 \mu \mathrm{g} / \mathrm{mL})$ plus $50 \mu \mathrm{L}$ PHA in conc. of $15 \mu \mathrm{g} / \mathrm{mL}$. The plates were incubated for 3 days under $5 \% \mathrm{CO}_{2}$ at $37^{\circ} \mathrm{C}$. Then $100 \mu \mathrm{L}$ of supernatant was removed from the wells and $10 \mu \mathrm{L}$ of MTT solution was added to all the wells. The plate was incubated further for $4 \mathrm{~h}$ at $37^{\circ} \mathrm{C}$. The MTT formazon was extracted from the cells using dimethyl-sulphoxide (100 $\mu \mathrm{L} /$ well). Then the OD was taken using an ELISA reader at a test wavelength of $570 \mathrm{~nm}$. All experiments were repeated at least two times.

\subsection{Statistical Analysis}

The Statistical Products and Service Solutions (SPSS) program was used for all analysis [21]. Data were expressed as mean \pm standard error (SE). Comparisons were tested using an analysis of variance (ANOVA) test. A difference was considered to be significant at $P<0.05$.

\section{Results}

\subsection{Isolation and Characterization of Camel Lactoferrin}

The results revealed that the cLf was separated around molecular weight of $80 \mathrm{kDa}$ (Figure 1).

\subsection{Antimicrobial Effect of Camel Lactoferrin}

The antimicrobial activity of the isolated cLf was investigated against Streptococcus agalactiae (S. agalactiae), Staphylococcus aureus (S. aureus), Escherichia coli (E. coli) and Pseudomonas aeruginosa (P. aerogenosa) strains. The cLf showed significant inhibitory effect against E. coli followed by $P$. aeruginosa, S. agalactiae

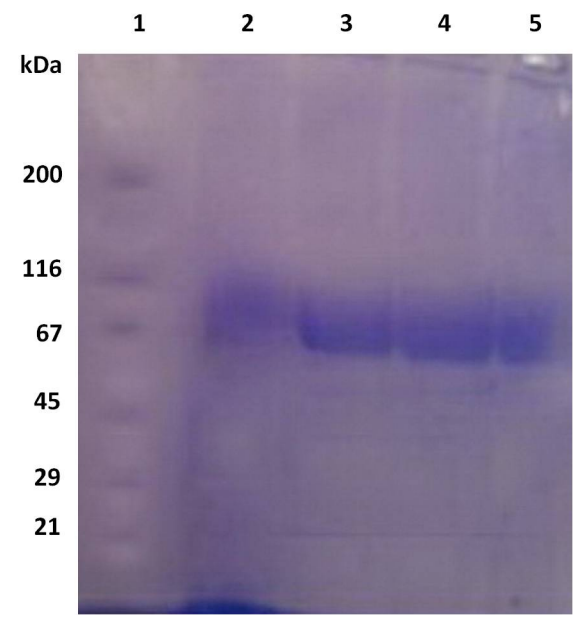

Figure 1. SDS-PAGE of various fractions of Lf purification from camel milk whey. Lane 1, Molecular weight marker; lane 2, Lf standard; lane 3-5, fractions eluted from SP-Sepharose.

and S. aureus (Table 1). The inhibition of growth by cLf was concentration-dependent in which a significant inhibitory effect of E-coli was observed in a conc. of 1 $\mathrm{mg} / \mathrm{mL}$ of cLf after $3 \mathrm{~h}$ and at conc. of $3 \mathrm{mg} / \mathrm{mL}$ after $1 \mathrm{~h}$ of incubation. Severe inhibition of growth was observed against $P$. aerogenosa and $S$. agalactiae at conc. of 3 $\mathrm{mg} / \mathrm{mL}$ after $6 \mathrm{~h}$ and $12 \mathrm{~h}$ of incubation respectively. $S$. aureus showed slight inhibition of growth at conc. of 3 $\mathrm{mg} / \mathrm{mL}$ in compared to control.

\subsection{Immunomodulator Effect of Camel Lactoferrin}

The immune effect of cLf was studied by lymphocyte transformation test (LTT). Phytohemagglutinin (PHA) was used as a control. The obtained results showed that the lymphocyte transformation mean value of PHA was $2.37 \pm 0.06$ (Table 2). While the lymphocyte transformations mean values of cLf alone at concentrations of 10 $\mu \mathrm{g} / \mathrm{mL}, 20 \mu \mathrm{g} / \mathrm{mL}$ and $50 \mu \mathrm{g} / \mathrm{mL}$ were $1.805 \pm 0.040$, $1.955 \pm 0.045$ and $2.39 \pm 0.053$ respectively (Table 2 ). The cLf increased lymphocyte transformations mean values in a dose dependant manner. The highest transformations mean value was at concentration of $50 \mu \mathrm{g} / \mathrm{mL}$. On the other side, the lymphocyte transformation mean values of cLf with PHA, at concentrations of $10 \mu \mathrm{g} / \mathrm{mL}$, $20 \mu \mathrm{g} / \mathrm{mL}$ and $50 \mu \mathrm{g} / \mathrm{mL}$ were $2.12 \pm 0.03,1.941 \pm 0.024$ and $1.861 \pm 0.1$ respectively (Table 2 ). This means cLf decreased lymphocyte transformations mean values in a dose dependant manner.

\section{Discussion}

Lactoferrin (Lf), in this work, was isolated and purified from camel milk whey using a cation exchange chroma- 
Table 1. Antimicrobial effect of camel lactoferrin (cLf) on E-coli, P. aeruginosa, S. aureus and S. agalactiae counts after 1, 3, 6, 12, 24 hours of incubation.

\begin{tabular}{|c|c|c|c|c|c|c|}
\hline \multirow{2}{*}{\multicolumn{2}{|c|}{ Items }} & \multicolumn{5}{|c|}{ Microbial count $(\mathrm{CFU} / \mathrm{mL})$ after } \\
\hline & & 1 hour & 3 hours & 6 hours & 12 hours & 24 hours \\
\hline \multirow{3}{*}{ E-coli count } & Control & 49.000 & 370.000 & $2.9 \times 10^{6}$ & $3.1 \times 10^{7}$ & $2.7 \times 10^{7}$ \\
\hline & cLf (1 mg/mL) & 35.000 & 15.000 & 8000 & 500 & CIG \\
\hline & cLf $(3 \mathrm{mg} / \mathrm{mL})$ & CIG & CIG & CIG & CIG & CIG \\
\hline \multirow{3}{*}{$\begin{array}{l}\text { P. aeruginosa } \\
\text { count }\end{array}$} & Control & $1.8 \times 10^{4}$ & $2.3 \times 10^{4}$ & $1.7 \times 10^{5}$ & $2.4 \times 10^{6}$ & $2.9 \times 10^{7}$ \\
\hline & $\operatorname{cLf}(1 \mathrm{mg} / \mathrm{mL})$ & 142.000 & 111.000 & 43.000 & 21.000 & 17.000 \\
\hline & cLf $(3 \mathrm{mg} / \mathrm{mL})$ & 107.000 & 93.000 & 17.000 & 950 & 950 \\
\hline \multirow{3}{*}{$\begin{array}{l}\text { S. aureus } \\
\text { count }\end{array}$} & Control & 87.000 & $2.3 \times 10^{6}$ & $2.7 \times 10^{7}$ & $2.9 \times 10^{8}$ & $2.2 \times 10^{8}$ \\
\hline & cLf (1 mg/mL) & 73.000 & $2.1 \times 10^{6}$ & $2.6 \times 10^{7}$ & $2.7 \times 10^{8}$ & $2.1 \times 10^{8}$ \\
\hline & cLf (3 mg/mL) & 56.000 & $1.7 \times 10^{6}$ & $2.0 \times 10^{7}$ & $2.1 \times 10^{8}$ & $1.9 \times 10^{8}$ \\
\hline \multirow{3}{*}{$\begin{array}{l}\text { S. agalactiae } \\
\text { count }\end{array}$} & Control & $0.7 \times 10^{6}$ & $2.6 \times 10^{6}$ & $3.4 \times 10^{7}$ & $2.9 \times 10^{8}$ & $3.6 \times 10^{8}$ \\
\hline & cLf (1 mg/mL) & $0.4 \times 10^{6}$ & $1.8 \times 10^{6}$ & $2.3 \times 10^{5}$ & $1.8 \times 10^{4}$ & $2.1 \times 10^{5}$ \\
\hline & cLf (3 mg/mL) & $2.2 \times 10^{5}$ & $1.9 \times 10^{5}$ & $1.0 \times 10^{4}$ & 1000 & 3300 \\
\hline
\end{tabular}

cLf: Camel lactoferrin; CIG: Complete inhibition of growth; N.B.: S. agalactiae was more diluted to be easily counted.

Table 2. Immunomodulator effect of camel lactoferrin (cLf) using lymphocyte transformation test (LTT).

\begin{tabular}{|c|c|c|c|c|c|c|c|}
\hline \multirow{2}{*}{ Items } & \multirow[t]{2}{*}{ PHA alone } & \multicolumn{3}{|c|}{ Camel lactoferrin alone } & \multicolumn{3}{|c|}{ Camel lactoferrin with PHA } \\
\hline & & $10 \mu \mathrm{g} / \mathrm{mL}$ & $20 \mu \mathrm{g} / \mathrm{mL}$ & $50 \mu \mathrm{g} / \mathrm{mL}$ & $10 \mu \mathrm{g} / \mathrm{mL}$ & $20 \mu \mathrm{g} / \mathrm{mL}$ & $50 \mu \mathrm{g} / \mathrm{mL}$ \\
\hline LTT means \pm SE & $2.37 \pm 0.06$ & $\begin{array}{c}1.805 \pm 0.040 \\
(P<0.05)\end{array}$ & $\begin{array}{c}1.955 \pm 0.045 \\
(P<0.05)\end{array}$ & $2.39 \pm 0.053^{\mathrm{n} . \mathrm{s}}$ & $\begin{array}{l}2.12 \pm 0.03 \\
(P<0.01)\end{array}$ & $\begin{array}{c}1.941 \pm 0.024 \\
(P<0.001)\end{array}$ & $\begin{array}{l}1.861 \pm 0.1 \\
(P<0.001)\end{array}$ \\
\hline
\end{tabular}

PHA: Phytohemagglutinin; n.s: non-significant.

tography on SP-Sepharose. Compared to the bovine species, camel whey contains a higher content of antimicrobial factors such as lysozyme, lactoferrin and immunoglobulins [8-10]. Variation in the composition of whey proteins from camel (Camelus dromedarius) colostrum and milk was recorded [22] and shown to be rich in protective proteins, especially lactoferrin, peptidoglycan recognition protein and immunoglobulins $\mathrm{IgG}_{2}$ and $\mathrm{IgG}_{3}$. Due to Lf large potential applications, many processing technologies have been developed to isolate high purity fractions. Cation-exchange chromatography is already used for the production of $\mathrm{Lf}$ at industrial scale $[14,16]$. This technology has the advantage of producing Lf with a high degree of purity ( $>90 \%$ dry basis). The limitation of this technology for large-scale applications lies with its high cost and its relatively low yield [23]. Characterization of camel Lf (cLf) was done using reduced polyacrylamide gel electrophoresis (SDS-PAGE). cLf was separated around molecular weight of $80 \mathrm{kDa}$. However, affinity membranes with immobilized triazinic dyes have not achieved yet good acceptance in the biotechnological industry, mainly because of their low capacity for proteins in comparison with the same legends immobilized on soft gels [24] and the dye leaching in the elution and regeneration steps [25]. Although, under equilibrium conditions, membranes show an acceptable chromatographic performance for Lf purification from bovine colostrums, better than the obtained with d-Sepharose, as a model of soft gels [26], the main problems affecting industrial utilization of adsorptive dye membranes, such as low capacity, dye leaching and pressure drop along the fiber axis need to be overcome. On the other side, the recovery of Lf from whey is a relatively difficult task, because not only the huge volume of whey needs to be dealt with, but also the major proteins complicate the separation process [27].

The cLf showed significant inhibitory effect against $E$. coli followed by P. aeruginosa, S. agalactiae and S. aureus. One of the first antimicrobial properties discovered for Lf was its role in sequestering iron from bacterial pathogens as in case of S. aureus [28] which is known to be resistant to antimicrobials. It was later demonstrated that Lf's bactericidal function has been attributed to its direct interaction with bacterial surfaces [29] and through an iron-independent mechanism [30] as in case of E. coli [31]. Biofilm formation, which was pro- 
posed as a colonial organization adhesion method for $P$. aeruginosa, is a well-studied phenomenon. Through biofilm formation, bacteria become highly resistant to host cell defense mechanisms and antibiotic treatment [32]. It is well known that some bacterial strains require high levels of iron to form biofilms. Thus, Lf's function as an iron chelator has been hypothesized to effectively inhibit biofilm formation through iron sequestration [33]. Occurrence in various milieus strongly emphasizes the significance of the structure-function relationship in the multifunctionality of the Lf [7].

Regarding the immune effect of cLf, the cLf increased lymphocyte transformations mean values in a dose dependant manner. The highest transformations mean value was of lactoferrin in conc. of $50 \mu \mathrm{g} / \mathrm{mL}$. This finding was agreed with [34] who reported that the addition of recombinant human lactoferrin (Talactoferrin Alfa (TLf)) to human peripheral blood or monocyte-derived dendritic cell cultures resulted in cell maturation, as evidenced by up-regulated expression of CD80, CD83, and CD86, production of proinflammatory cytokines, and increased capacity to stimulate the proliferation of allogeneic lymphocytes. In addition, this finding was agreed to some extend with [35] who found that the effects of Lf in experimental models were differential and dependent on an individual PBMC reactivity, mitogen or alloantigen and Lf concentration. Generally, lymphocytes from donors responsive to Lf exhibited higher proliferation indices to PHA when compared with non-responsive individuals, suggest that the differential action of Lf might be due to its ability to sense the activation status of lymphocytes, although he mentioned that data on Lf effects on mitogen-induced proliferation are scarce, though fairly consistent both in the mouse and human systems. It has been demonstrated that human and bovine lactoferrin inhibit proliferative responses in vitro.

In addition, the cLf decreased lymphocyte transformations mean values in a dose dependant manner when combined with PHA. This opinion goes hand in hand with [36] who reported that purified lactoferrin, isolated from human milk, was tested for its effect on human Tlymphocyte proliferative responses to Phytohemagglutinin (PHA) and to alloantigen in mixed lymphocyte culture. Lf inhibited proliferation in both assays in a dosedependent manner. The suppressive effect was not due to Lf mediated cytotoxicity since washing cells that had been pre-incubated with $\mathrm{Lf}$ restored their proliferative activity. Lf was most effective in suppressing the PHA response when added within $24 \mathrm{~h}$ of culture initiation. Iron saturated Lf failed to inhibit PHA-induced proliferation, suggesting that the mechanisms of suppression involve the chelating property of Lf. The suppressive effect of Lf on T-lymphocyte proliferative response in vitro supports the notion that Lf has significant immunoregulatory potential in vivo. The same agreement was concluded by [35] that the effects of Lf on the proliferative response of lymphocytes to PHA were generally stimulatory at lower and inhibitory at higher concentrations of Lf. The increased production of cytokines may play a significant role in the down-regulation of mitogen-induced lymphocyte proliferation in the presence of Lf.

\section{Conclusion and Recommendation}

In conclusion, these results suggest that $\mathrm{cLf}$ is a potent natural antimicrobial and novel immunomodulator agent. The extensive uses of Lf in the treatment of various infectious diseases in animals and humans have been the driving force in Lf research, however, a lot of work is required to obtain a better understanding of its activity. Further studies will be needed for molecular cloning, promoter analysis and identification of camel lactoferrin gene.

\section{Acknowledgements}

This research was financially supported by the dean of Scientific Research (Project No.1-433-1582), Faculty of Applied Medical Sciences (Turaba), Taif University, KSA.

\section{REFERENCES}

[1] K. I. Ereifej, M. H. Alu'datt, H. A. AlKhalidy, I. Alli and T. Rababah, "Comparison and Characterization of Fat and Protein Composition for Camel Milk from Eight Jordanian Locations," Food Chemistry, Vol. 127, No. 1, 2011, pp. 282-289. http://dx.doi.org/10.1016/j.foodchem.2010.12.112

[2] O. A. Al Haj and H. A. Al Kanhal, "Compositional, Technological and Nutritional Aspects of Dromedary Camel Milk," International Dairy Journal, Vol. 20, No. 12, 2010, pp. 811-821. http://dx.doi.org/10.1016/j.idairyj.2010.04.003

[3] I. Phillips, M. Casewell, T. Cox, B. De Groot, C. Friis, R. Jones, C. Nightingale, R. Preston and J. Waddell, "Does the Use of Antibiotics in Food Animals Pose a Risk to Human Health? A Critical Review of Published Data," Journal of Antimicrobial Chemotherapy, Vol. 53, No. 1, 2004, pp. 28-52. http://dx.doi.org/10.1093/jac/dkg483

[4] P. J. Rajala-Schultz, K. L. Smith, J. S. Hogan and B. C. Love, "Antimicrobial Susceptibility of Mastitis Pathogens from First Lactation and Older Cows," Veterinary Microbiology, Vol. 102, No. 1-2, 2004, pp. 33-42. http://dx.doi.org/10.1016/j.vetmic.2004.04.010

[5] A. A. Adesiyun, S. Stoute and B. David, "Pre-Processed Bovine Milk Quality in Trinidad: Prevalence and Characteristics of Bacterial Pathogens and Occurrence of Antimicrobial Residues in Milk from Collection Centresm," Food Control, Vol. 18, No. 4, 2007, pp. 312-320. 
http://dx.doi.org/10.1016/j.foodcont.2005.10.012

[6] P. P. Ward, E. Paz and O. M. Conneely, "Multifunctional Roles of Lactoferrin: A Critical Overview," Cellular and Molecular Life Sciences, Vol. 62, No. 22, 2005, pp. 25402548. http://dx.doi.org/10.1007/s00018-005-5369-8

[7] A. S. Naidu, "Lactoferrin: Natural, Multifunctional, Antimicrobial," CRC Press LLC, Florida, 2000. http://dx.doi.org/10.1201/9781420041439

[8] E. I. El-Agamy, "Effect of Heat Treatment on Camel Milk Proteins with Respect to Antimicrobal Factors: A Comparison with Cows' and Buffalo Milk Protein," Food Chemistry, Vol. 68, No. 2, 2000, pp. 227-232. http://dx.doi.org/10.1016/S0308-8146(99)00199-5

[9] D. Levieux, A. Levieux, H. El-Hatmi and J. P. Rigaudière, "Immunochemical Quantification of Heat Denaturation of Camel (Camelus Dromedarius) Whey Proteins," Journal of Dairy Research, Vol. 72, No. 1, 2006, pp. 1-9.

[10] G. Konuspayeva, B. Faye, G. Loiseau and D. Levieux, "Lactoferrin and Immunoglobulin Contents in Camel's Milk (Camelus bactrianus, Camelus dromedarius, and Hybrids) from Kazakhstan," Journal of Dairy Science, Vol. 90, No. 1, 2007, pp. 38-46. http://dx.doi.org/10.3168/jds.S0022-0302(07)72606-1

[11] S. Kappeler, Z. Farah and Z. Puhan, "Alternative Splicing of Lactophorin mRNA from Lactating Mammary Gland of the Camel (Camelus dromedarius)," Journal of Dairy Science, Vol. 82, No. 10, 1999, pp. 2084-2093. http://dx.doi.org/10.3168/jds.S0022-0302(99)75450-0

[12] El-RM Redwan and Tabll, "Camel Lactoferrin Markedly Inhibits Hepatitis C Virus Genotype 4 Infection of Human Peripheral Blood Leukocytes," Journal of Immunoassay Immunochemistry, Vol. 28, No. 3, 2007, pp. 267277. http://dx.doi.org/10.1080/15321810701454839

[13] Y. Liao, X. Du and B. Lönnerdal, "miR-214 Regulates Lactoferrin Expression and Pro-Apoptotic Function in Mammary Epithelial Cells," Journal of Nutrition, Vol. 140, No. 9, 2010, pp. 1552-1556. http://dx.doi.org/10.3945/jn.110.124289

[14] P. H. C. Van Berkel, M. E. J. Geerts, H. A. van Veen, P. M. Kooiman, H. A. Pieper, A. de Boer and J. H. Nuijens, "Glycosylated and Unglycosylated Human Lactoferrins Both Bind Iron and Show Identical Affinities towards Human Lysozyme and Bacterial Lipopoly-Saccharide, but Differ in Their Susceptibilities towards Tryptic Proteolysis," Biochemical Journal, Vol. 312, No. 1, 1995, pp. 107-114.

[15] E. I. El-Agamy, R. Ruppanner, A. Ismail, C. P. Champagne and R. Assaf, "Purification and Characterization of Lactoferrin, Lactoperoxydase, Lysozyme and Immunoglobulins from Camel's Milk," International Dairy Journal, Vol. 6, No. 2, 1996, pp. 129-145. http://dx.doi.org/10.1016/0958-6946(94)00055-7

[16] C. Conesa, L. Sanchez, C. Rota, M. D. Pérez, M. Calvo, S. Farnaud and R. W. Evans, "Isolation of Lactoferrin from Milk of Different Species: Calorimetric and Antimicrobial Studies," Comparative Biochemistry and Physiology, Part B, Vol. 150, 2008, pp. 131-139.

[17] U. K. Laemmli, “Cleavage of Structural Proteins during the Assembly of the Head of Bacteriophage T4," Nature, Vol. 227, 1970, pp. 680-685. http://dx.doi.org/10.1038/227680a0

[18] H. A. E. Asfour, M. H. Yassin and A. M. Gomaa, "Antibacterial Activity of Bovine Milk Lactoferrin against Some Mastitis Causative Pathogens with Special Regards to Mycoplasmas," International Journal of Microbiological Research, Vol. 1, No. 3, 2010, pp. 97-105.

[19] N. Richardson, "Standard Methods for the Examination of Dairy Product," 15th Edition, APHA, Washington DC, 1985.

[20] G. Rai-Elbalhaa, J. L. Pellerin, G. Bodin, H. A. Abdullah and H. Hiron, "Lymphoblastic Transformation Assay of Sheep Peripheral Blood Lymphocytes: A New Rapid and Easy-to-Read Technique," Comparative Immunology, Microbiology \& Infectious Diseases, Vol. 8, No. 3-4, 1985, pp. 311-318. http://dx.doi.org/10.1016/0147-9571(85)90010-4

[21] M. Borenstein, H. Rothstein and J. Cohen, "Sample Power Statistics 10,” SPSS Inc., Chicago, 1997.

[22] H. El-Hatmi, J.-M. Girardet, J.-L. Gaillard, M. H. Yahyaoui and H. Attia, "Characterisation of Whey Proteins of Camel (Camelus dromedarius) Milk and Colostrum," Small Ruminant Research, Vol. 70, No. 2-3, 2007, pp. 267-271.

http://dx.doi.org/10.1016/j.smallrumres.2006.04.001

[23] E. Fuda, P. Jauregi and D. L. Pyle, "Recovery of Lactoferrin and Lactoperoxidase from Sweet Whey Using Colloidal Gas Aphrons (CGAs) Generated from an Anionic Surfactant," AOT Biotechnological Progress, Vol. 20, No. 2, 2004, pp. 514-525. http://dx.doi.org/10.1021/bp034198d

[24] R. Ghosh, "Protein Separation Using Membrane Chromatography: Opportunities and Challenges," Journal of Chromatograph, Vol. A952, No. 1-2, 2002, p. 13.

[25] D. L. Stewart, D. Purvis and C. R. Lowe, "Affinity Chromatography on Novel Perfluorocarbon Supports: Immobilisation of C.I. Reactive Blue 2 on a Polyvinyl AlcoholCoated Perfluoropolymer Support and Its Application in Affinity Chromatography," Journal of Chromatograph, Vol. A510, No. 27, 1990, p. 177.

[26] F. J. Wolman, D. Gonzalez Maglio, M. Grasselli and O. Cascone, "One-Step Lactoferrin Purification from Bovine Whey and Colostrum by Affinity Membrane Chromatography," Journal of Membrane Science, Vol. 288, No. 1-2, 2007, pp. 132-138.

http://dx.doi.org/10.1016/j.memsci.2006.11.011

[27] S. Yoshida and X. Y. Ye, "Isolation of Lactoperoxidase and Lactoferrin from Bovine Milk Acid Whey by Carboxymethyl Cation Exchange Chromatography," Journal of Dairy Science, Vol. 74, No. 5, 1991, pp. 1439-1444. http://dx.doi.org/10.3168/jds.S0022-0302(91)78301-X

[28] R. S. Bhimani, Y. Vendrov and P. Furmanski, "Influence of Lactoferrin Feeding and Injection against Systemic Staphylococcal Infections in Mice," Journal of Applied Microbiology, Vol. 86, No. 1, 1999, pp. 135-144. http://dx.doi.org/10.1046/j.1365-2672.1999.00644.x

[29] S. Farnaud and R. W. Evans, "Lactoferrin: A Multifunctional Protein with Antimicrobial Properties," Molecular 
Immunology, Vol. 40, No. 7, 2005, pp. 395-405. http://dx.doi.org/10.1016/S0161-5890(03)00152-4

[30] P. Valenti and G. Antonini, "Lactoferrin: An Important Host Defense against Microbial and Viral Attack," Cellular and Molecular Life Sciences, Vol. 62, No. 22, 2005, pp. 2576-2587. http://dx.doi.org/10.1007/s00018-005-5372-0

[31] A. Nacimiento and L. O. Giugliano, "Human Milk Fractions Inhibit the Adherence of Diffusely Adherent Escherichia coli (DAEC) and Enteroaggregative E. coli (EAEC) to HeLa Cells," FEMS Microbiological Letters, Vol. 184, No. 1, 2000, pp. 91-94.

[32] P. K. Singh, M. R. Parsek, E. P. Greenberg and M. J. Welsh, "A Component of Innate Immunity Prevents Bacterial Biofilm Development," Nature, Vol. 417, No. 6888, 2002, pp. 552-555. http://dx.doi.org/10.1038/417552a

[33] E. D. Weinberg, "Suppression of Bacterial Biofilm Formation by Iron Limitation," Medical Hypotheses, Vol. 63, No. 5, 2004, pp. 863-865. http://dx.doi.org/10.1016/j.mehy.2004.04.010

[34] R. Gonzalo, D. Yang, P. Tewary, A. Varadhachary and J. J. Oppenheim, "Lactoferrin Acts as an Alarmin to Promote the Recruitment and Activation of APCs and AntigenSpecific Immune Responses," Journal of Immunology, Vol. 180, No. 10, 2008, pp. 6868-6876.

[35] M. Zimecki, S. Dariusz, A. S. Pniak and L. K. Marian, "Lactoferrin Regulates Proliferative Response of Human Peripheral Blood Mononuclear Cells to Phytohaemaglutinin and Mixed Lymphocyte Reaction," Archivum Immunologiae et Therapiae Experimentalis, Vol. 49, No. 2, 2001, pp. 147-154.

[36] E. R. Richie, J. K. Hilliard, R. Gilmore and D. J. Gillespie, "Human Milk Derived Lactoferrin Inhibits Mitogen and Alloantigen Induced Human Lymphocyte Proliferation," Journal of Reproductive Immunology, Vol. 12, No. 2, 1987, pp. 137-148.

http://dx.doi.org/10.1016/0165-0378(87)90041-6 